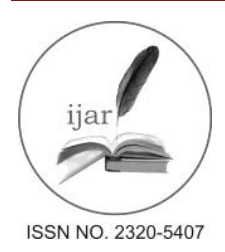

Journal homepage: http://www.journalijar.com

Journal DOI: $\underline{\text { 10.21474/IJAR01 }}$

RESEARCH ARTICLE

\title{
THE PROVISION OF THE RIGHTS OF WITNESS TO A LAWYER AS ONE OF THE GUARANTEES OF FAIR JUSTICE.
}

Dildora Bazarova Baxadirovna

Associate Professor of "Criminalistics" department, Tashkent State university of Law.

\section{Manuscript Info \\ Manuscript History: \\ Received: 14 February 2016 \\ Final Accepted: 19 March 2016 \\ Published Online: April 2016 \\ Key words: \\ criminal procedure, witness, lawyer. \\ *Corresponding Author}

Abstract

\section{Dildora Bazarova}

Baxadirovna

Copy Right, IJAR, 2016,. All rights reserved.

\section{Introduction:-}

The legitimate interests of the accused, the victim, but also the witness must be securely protected from violation of the rights in criminal proceedings.

One of the institutions designed to serve as an additional guarantee for the protection of fundamental human rights, in particular to ensure the constitutional right to professional legal assistance imposed by the reform of the judicial system, is the institution of provision lawyers to witness.

The law "On amendments and additions to some legislative acts of the Republic of Uzbekistan in connection to improvement of the institution of lawyer "[1] which has been developed in accordance with the Presidential decree of May 1, 2008 № UP-3993 "On measures to further reform of the institution of lawyers in the Republic of Uzbekistan"[2], aims to provide lawyer to witness in criminal proceedings.

As a rule, to perform the tasks the criminal proceedings there is need to involve various organs, officials and citizens to provide a supporting role in relation to the investigation and adjudicating criminal cases, the enforcement of court decisions, ensuring the rights and legitimate interests of participants in the case. The other group of persons who involved carrying out occasional tasks to assist in investigating and adjudicating certain procedural issues. This group includes a witness.

\section{Analysis of problems in current legislation:-}

According to article 65 of the Criminal Procedure Code (CPC) of the Republic of Uzbekistan any person who is aware of any circumstances of the criminal case can be called as a wetness to establish the truth during criminal proceedings. Witness, as a source of evidentiary information, created by the circumstances of the events under investigation and therefore it is not replaced as party to the criminal proceedings. His indispensability does not allow the combination of the duties of the witness with other participants.

The witness appears in the case since he is called to the investigator, prosecutor or court. From this moment, he will have the rights and obligations, and also the responsibility, including criminal. However, according to it E.V.Skoba 
[3,P-27] the person who is called as a witness for the first time in criminal proceedings, perhaps not yet fully understands the significance of their testimony, and prepared to sign anything. In practice, it is not excluded cases of mental, physical and other pressure to the witness in order to obtain "necessary" evidence. Thus the nullity of such testimony is not always easy to prove. Analysis of investigative practice shows that there are cases when as witnesses are questioned so-called "suspected persons". Having received necessary evidence from the person as a witness, then he may be questioned as a suspect and accused. Meanwhile, if being accused to participation in a criminal case as a suspect (accused) person has the right to refuse to testify, the witness under threat of criminal liability must report all required information [4, P-28]. Timely assistance to the witness in these cases is able to prevent or eliminate possible violations of his rights including to establish various kinds of illegal influence on him for purposes of giving them false testimony, to identify an honest mistake or to prevent other undesirable effects [5, P-97].

Introduction of the Institute of lawyers aims to protect of the rights and legitimate interests of the witness's from these and other negative situations, which also leads the further democratization of the criminal proceedings. The article 66 of the CPC strengthened the right of a witness to lawyer, and participation of lawyer with a witness involved in the investigation processes. Article 66-1 of the CPC, defines the lawyer of witness a person duly authorized to defend the rights and legitimate interests of the witness and provide him with the necessary legal assistance. It is established that the person performing the protection of interests of the parties in a criminal case, can not be a lawyer for a witness in the case.

Let us consider the question of joining a lawyer of witness in criminal proceedings. The analysis of the rules of the CPC shows that the lawyer may be invited by the witness, since according to part three of article 66-1 of the CPC lawyer to witness is allowed to participate in the case from the moment of the call by witness and presenting certificates and representation order. This means that the lawyer of the witness is a contractual representative. Therefore, people with low incomes can not use the services of a lawyer. This situation is also, of course, violate the rights and legitimate interests of these participants in the criminal process, and infringes on their constitutional right to professional legal assistance.

This situation can be remedied by making amendments to the criminal procedure law, in particular article 66-1 of the CPC to supplement the second part as follows: "At the request of the witness, not having sufficient income to pay for a lawyer, the lawyer may be appointed by investigator, prosecutor or court, and costs should be paid by public funds in the manner determined by the Cabinet of Ministers."

This would fully ensure the constitutional right to legal assistance in such a party to the criminal proceedings as a witness.

In addition, the fourth part of article 66-1 of the CPC has internal contradictions. On the one hand, the lawyer of the witness shall be entitled to participate in the interrogation of a witness, on the other hand, it is established that the lawyer of the witness has the right to question witnesses with the permission of the person conducting the interrogation. If a lawyer is involved in the questioning of the witness, thus permission of the person conducting the interrogation is not required. In accordance with article 53 of the CPC the lawyer has the right to participate in the interrogation of the suspect, and has the right to question the suspect, accused, witnesses, experts, specialists. The exercise of this right of lawyer (defense) is not dependent on the will of the person conducting the interrogation.

And in the case of a lawyer witness exercise of his right to ask questions is dependent on the will of the person conducting the interrogation. In cases where the person conducting the interrogation of the witness, does not allow the lawyer to ask the questions to the witness, these issues are not recorded in criminal file. Such an infringement of the right of the lawyer of witness will prevent the establishment of certain circumstances, which of course have a negative impact on the objective establishment of the truth in a criminal case. In our view, the wording in the fourth part of article 66-1 of the CPC "ask questions to the witness with the permission of the person conducting the interrogation" should be replaced by "after the examination of a witness the person conducting the interrogation, to ask questions to witnesses" that will create conditions for the effective participation of a lawyer in the questioning of witnesses.

It remains unclear the rights of a witness in the situation where witness involved in the investigation with a lawyer (defense). It concerns when in the absence of a lawyer, the witness is entitled to refuse to participate in the 
investigation, for instance, to give evidence at the interrogation. Should the investigator offer a replacement lawyer of the witness, in case of failure to appear of his lawyer? There is a legislative gap in the law regarding the timeframe to ensure the appearance of the lawyer for witness or his replacement in the case if one can not participate.

According to E.A. Popov, "the right of a witness ... to use the services of the lawyer as a means of protecting his rights, and any limitation of this right implies the illegality and, therefore, the inadmissibility of the witness testimony as evidence in a criminal case, if they are received as a result of limiting the right to testify in the presence of a lawyer" [6, P-102].

At the same time, the witness have no right to refuse to testify, the article 117 of CPC contains a provision on the prevention of the witness on criminal liability for refusal to testify; other cases where persons can not be questioned as witnesses, or may be questioned only with their consent as stipulated by law (article 115, 116 of the CPC). Consequently, the right of the witness to have a lawyer can be provided if there is a contract with a lawyer to provide legal assistance, as the legislator establishes the right of a witness, not an obligation of the inquirer, investigator, prosecutor, witness to provide a lawyer. Any other, of course, will contribute to the systematic failures of investigative actions with the participation of witnesses.

But taking into account that conclusion an agreement on legal assistance with lawyer, first requires from the witness awareness of this right and, secondly, a certain time, and the witness should be warned of the right to appear for questioning with a lawyer. Without such a provision the right to legal assistance it turns into an empty declaration.

A similar point of view expressed by L.G.Ton, who notes that "the accused (suspect) provided guarantees of the right to defense, because the agenda contains a reference to the right to invite the defense on their own or apply for ensuring the participation of the defense investigator in the manner prescribed by article 50 of the CPC. According to the legislation a witness:

1. presumed to have legal literacy and awareness of any person who is called to testify as a witness.

2. Or the investigator, calling for interrogation shall besides the information contained in the agenda, to inform the witness about the right to a lawyer;

3. Or before the interrogation investigator acquainted with the witness of his entitlement, should take into account and be guided by the expression of the will to invite a lawyer to create all necessary conditions for the implementation of its mandate "[7, P-32].

In our view, the purpose of addressing these issues in legislation would be appropriate to add in the second part of article 97 of the CPC the following sentence.

"In the invitation letter for interrogation it must be explained in detail the rights and duties of persons who called for questioning, regardless from the knowledge and capability of the person".

This rule together with the rules set forth in Article 100 of the CPC, would serve the interests of the rights of the person who called in for questioning.

Another issue related to the participation in a criminal trial lawyer of the witness, which deserves special attention, is the issue of guarantees of the legal aid in relation to the witness. Note that legal assistance and as an idea and as a subject of legal regulation, and as a kind of professional activity takes meaning and the true social value in terms of law and order, provided by the legal state [8, P-277]. This means that the provision of professional legal assistance, in particular, to the witness must be backed up by guarantees. One of these safeguards should extend the ban on questioning the lawyer of the witness about any circumstances became known to him in connection with the provision of legal aid.

There are two aspects that needed to be addressed. Firstly, the possibility of questioning the lawyer of the witness as a witness will create some discomfort to witness and be a hindrance to the provision of legal aid by the lawyer. Meanwhile, as stressed S.Latypov with which we agree, in the relations between a lawyer and witness, confidentiality plays an important role, since the emergence of mutual trust between them, no doubt, based on the strict observance of lawyer-client privilege, built in one of the basic principles of law in the Republic of Uzbekistan [9, P-109]. One can notice that in accordance with Article 9 of the Law "On the Lawyer" of the Republic of Uzbekistan, the subject of lawyer (advocate) secrecy includes the essence of consultations, advice, explanations 
given by the client from lawyers; as well as all other information relating to the lawyer's conversations with the client.

Second, the legislature can not exclude the right of the lawyer to give testimony in appropriate cases where his client is interested in the disclosure of certain information. It will comply with the provisions of the law that the close relatives of the suspect, the defendant may be questioned as witnesses or victims of the circumstances relating to the suspect, only with the consent of accused. Since the process of providing legal aid to the witness, who is a close relative of such persons, the lawyer can get information from a witness regarding the circumstances of the crime of his close relatives. This information may be disclosed only with the consent of the witnesses.

Based on the above, in our opinion, the lawyer of the witness should be included in the category of persons who can be questioned only with the consent of the client. To this end, we recommend to amend the second part of article 116 of the CPC as follows:

"The lawyer of the witness can be questioned about circumstances which became known to him due to legal aid and relating to his client, only with the consent of the client (witness)".

This addition is also aimed at protecting those who are questioned as a witness, but, at the same time checked their involvement in the crime, but there are no formal bases for the recognition, suspicion, or further accusation them.

\section{Conclusion:-}

Thus, as a result of analysis of current legislation we conclude there are no legal mechanisms to ensure providing the witness with lawyer and to guarantee this right. In order to ensure timely provision of the constitutional rights of professional legal assistance to witness, we suggest legally obligate investigator to inform witness, in invitation letter, about the right to have a lawyer the witness, to explain in greater detail the rights and duties of persons called for questioning, regardless from the knowledge and capability of the person.

In addition, taking into account that often persons suspected of a crime are interrogated as a witness first, the lawyer of the witness should be included in the category of persons who may be questioned about the circumstances which became known to him due to legal aid and relating to his client, only with the consent of the client (witness).

\section{References:-}

1."Collection of Laws of the Republic of Uzbekistan", 2008, № 52, P. 514;

Bulletin of Oliy Majlis of Uzbekistan, 2008, № 12, P. 641.

2. "Collection of the legislation of the Republic of Uzbekistan", 2008, №18, P.144; Bulletin of Oliy Majlis of Uzbekistan, 2008, N5 P.252

3. Skoba E.B. Provision of qualified legal assistance to the witness // J. Law practice. - 2009. - № 3. - P. 27.

4. Skoba E.B. Provision of qualified legal assistance to the witness // J. Law practice. - 2009. - № 3. - P. 28.

5. Popov E.A. The lawyer as a member of the criminal process in the pre-trial stages: Dissertation for Candidacy of Juridical sciences. - Krasnodar, 2004. - P. 97.

6. Popov E.A. The lawyer as a member of the criminal process in the pre-trial stages: Dissertation for Candidacy of Juridical sciences. - Krasnodar, 2004. - P. 102.

7. Ton L.G. Some aspects of a lawyer of the witness in the criminal trial // Some areas of reform of the legal profession: Proceedings of the Round Table, 2009. - T .: Publishing TSIL, 2009. - P.32.

8. Dosymbekov R.Sh. Single issues of the constitutional right of citizens to legal assistance and protection // Ensuring the constitutional rights of citizens in pretrial stages of the criminal process: the international scientificpractical conference, Astana, 26-27 August 2005 - Almaty: DP "Edelweiss", 2006. - P. 277.

9. Latypov S.I. lawyer-client privilege and the individual problems of its preservation // Some areas of reform of the legal profession: Proceedings of the Round Table, 2009. - T .: Publishing TSIL, 2009. - P.109. 